\title{
Development of Primers and Probes for Genus and Species Specific Detection of 'Candidatus Liberibacter Species' by Real-Time PCR
}

G. Ananthakrishnan, N. Choudhary, and Avijit Roy, University of Florida, CREC, Lake Alfred, FL 33850; V. G. Sengoda, USDAARS, Yakima Agricultural Research Laboratory, Wapato, WA 98951; E. Postnikova, USDA-ARS, FDWSRU, Fort Detrick, MD 21702; J. S. Hartung, USDA-ARS, MPPL, Beltsville, MD 20705; A. L. Stone, V. D. Damsteegt, and W. L. Schneider, USDA-ARS, FDWSRU, Fort Detrick, MD 21702; J. E. Munyaneza, USDA-ARS, Yakima Agricultural Research Laboratory, Wapato, WA 98951; and R. H. Brlansky, University of Florida, CREC, Lake Alfred, FL 33850

\begin{abstract}
Ananthakrishnan, G., Choudhary, N., Roy, A., Sengoda, V. G., Postnikova, E., Hartung, J. S., Stone, A. L., Damsteegt, V. D., Schneider, W. L., Munyaneza, J. E., and Brlansky, R. H. 2013. Development of primers and probes for genus and species specific detection of 'Candidatus Liberibacter species' by real-time PCR. Plant Dis. 97:1235-1243.

Huanglongbing (HLB), also known as citrus greening, is currently the most devastating disease impacting citrus production. The disease is associated with three different 'Candidatus Liberibacter species', ' $\mathrm{Ca}$. Liberibacter asiaticus', ' $\mathrm{Ca}$. Liberibacter americanus', and ' $\mathrm{C} a$. Liberibacter africanus', which induce similar and overlapping symptoms. When HLB-symptomatic trees are tested, one of the Candidatus Liberibacters is normally detected by conventional or real-time PCR (qPCR). The most widely used assays use primers and probes based on the $16 \mathrm{~S}$ ribosomal RNA (rRNA) gene. The $16 \mathrm{~S}$ rRNA-based assays to detect the three species are species-specific and must be performed sequentially. We describe a single assay that detected all species of ' $C a$. Liberibacter' at the genus level, providing increased convenience. Recent molecular analyses of ' $\mathrm{Ca}$. Liberibacter species' and other bacteria suggest that the $r p o B$ gene (encoding the $\beta$-subunit of RNA polymerase) provides an alternative target for bacterial identification.

We report here the design of a single pair of degenerate primers and a hybridization probe corresponding to the $r p o B$ region and their application for the detection of all three citrus ' $\mathrm{Ca}$. Liberibacter species', enabling detection of ' $\mathrm{Ca}$. Liberibacter' at the genus level. In addition, species-specific primers and probes based on the $r p l J / r p l K$ genes were designed and used for detection at the species level in a multiplexed format. Both the genus- and species-specific assays were validated in both SYBR Green I and TaqMan formats, and with both plant and insect extracts that contained the pathogen. These one-step qPCR diagnostic methods are useful for the detection of all species of Liberibacter infecting citrus. In addition, the degenerate genus-specific primers and probe successfully detected ' $\mathrm{Ca}$. Liberibacter solanacearum', a psyllid-transmitted pathogen associated with disease in tomato, carrot, and potato.
\end{abstract}

Huanglongbing (HLB) is a destructive citrus disease associated with phloem-limited bacteria of the Candidatus genus Liberibacter. Many more than 100 million citrus trees have been destroyed by the disease throughout the world (10). These bacteria are transmitted by two psyllid vectors, Diaphorina citri and Trioza erytrae. The disease severely affects citrus production in Brazil, China, India, South Africa, and the United States. HLB-affected plants can be visually identified by symptoms that include chlorotic shoots, mottled leaves, and lopsided, small, and miscolored fruit. Symptoms often can be confused with nutrient and/or other disease problems. There are three 'Candidatus Liberibacter species' known to be associated with HLB-affected citrus (' $\mathrm{Ca}$. Liberibacter asiaticus', ' $C a$. Liberibacter americanus', and ' $C a$. Liberibacter africanus'). ' $C a$. Liberibacter asiaticus' has a wide host range in rutaceous species (11). HLB disease management is difficult and expensive, and there is no immediate solution. Asymptomatic infections are common throughout the year, and symptoms are produced only at later stages of the disease. There is also a prolonged latent period before symptoms become apparent in infected plants. In addition, phytoplasmas (group 16SrIX and 16SrI) have been found associated with symptoms that are indistinguishable from those of HLB in Brazil and China, respectively $(4,32)$. The discovery of phytoplasmas associated with symptoms indistinguishable from HLB puts a premium on the value of accurate identification

Corresponding author: R. H. Brlansky, E-mail: rhby@ufl.edu

Accepted for publication 24 March 2013.

http://dx.doi.org/10.1094/PDIS-12-12-1174-RE

(C) 2013 The American Phytopathological Society of the unculturable bacterium. In the absence of accurate identification of the pathogen corresponding to a particular disease syndrome, control methods may be misdirected. Identification of ' $\mathrm{Ca}$. Liberibacter spp.' at both the genus and species levels is also important for regulatory issues, to facilitate the identification of ' $\mathrm{Ca}$. Liberibacter spp.' in new hosts and insect vectors, to assist in management of HLB-affected trees, and for the development of HLBfree nursery materials.

Serological detection methods currently are not available. A variety of molecular approaches have been used to detect and differentiate ' $C a$. Liberibacter spp.' DNA probes (dot-blot hybridization) were made from the DNA sequence of the $\beta$-operon for detection of ' $\mathrm{Ca}$. Liberibacter asiaticus' and ' $\mathrm{Ca}$. Liberibacter africanus' (34). Conventional PCR methods have been used to detect ' $\mathrm{Ca}$. Liberibacter asiaticus' and ' $\mathrm{Ca}$. Liberibacter africanus' $(13,33)$. Recently, quantitative polymerase chain reaction (qPCR) using $16 S$ rDNA primers (19-21) and loop-mediated isothermal amplification (LAMP) using primers for the tufB to the $r p o B$ gene (29) have been used for detection of Liberibacter species.

RNA polymerase (RNAP) is a crucial enzyme in the transcriptional process and is the final checkpoint for regulatory pathways controlling gene expression in all living organisms (2). The majority of the catalytic function of RNAP is carried out by the $\beta$ subunit, which is encoded by the $r p o B$ gene (14). Among the core bacterial genes, $r р о B$ has emerged as one of the few potential candidates for the molecular identification of bacteria at the subspecies level $(1,3)$. This gene is described as possessing the same key attributes as $16 \mathrm{~S}$ rDNA, in that it is common to all bacteria and is a mosaic of conserved as well as variable sequence domains (6). The $r p o B$ gene exists as a single copy in bacterial genomes (24), whereas ' $\mathrm{Ca}$. Liberibacter asiaticus' contains three copies of $16 \mathrm{~S}$ rDNA $(9,16)$. The rpoB DNA region has been utilized in previous 
studies of the phylogenetic analysis and identification of bacteria such as Mycobacterium (15), Borrelia (18), Bartonella (30), Staphylococcus (8), and Legionella (17).

Our first objective was to develop and validate a set of qPCR assays that would identify all ' $\mathrm{Ca}$. Liberibacter' associated with citrus HLB and associated psyllid vectors at the level of species. For ease of use, we wanted to design these assays so that they could be used in a single multiplexed assay. Our second objective was to develop and validate a single genus-specific assay for all Liberibacters. These assays are based on the $r p o B$ and $r p l J / r p l K$ genes, encoding the $\beta$-subunit of RNA polymerase and the L10 and L11 proteins of the 50S ribosome, respectively. Primers and probes developed from the $r p o B$ region of ' $C a$. Liberibacter species' were tested for genus-specific detection of all three citrus associated ' $\mathrm{Ca}$. Liberibacter species' in a single qPCR assay. In addition, although assays for the detection of individual species of ' $\mathrm{Ca}$. Liberibacter spp.' from citrus have been described (19), they must be performed sequentially, and a single multiplexed PCR assay for simultaneous and species-specific identification of all three known ' $C a$. Liberibacter species' associated with HLB has not been reported. The rplJ and $r p l L$ genes have been used for detection of ' $\mathrm{Ca}$. Liberibacter asiaticus' and ' $\mathrm{Ca}$. Liberibacter americanus' in Brazil and China (31,35). ' $C a$. Liberibacter solanacearum' was recently associated with diseases of potatoes in the United States $(12,25,26)$, tomatoes in New Zealand (22), and carrot in Europe (28), and the $r p l J$ gene sequence has been used for its identification $(22,27)$. This study reports the first application of the rpoB gene for detection and identification of ' $\mathrm{Ca}$. Liberibacter spp.' at the level of genus. We also compare the use of the rpoB- and $r p l J / r p l K$-based primers and probes with the use of the current $16 S$ rDNA primers and probes in qPCR for the detection of the various ' $C a$. Liberibacter species'. Lastly, we compared the sensitivities of the three assays ( $16 \mathrm{~S} \mathrm{rRNA}, \mathrm{rpoB}$, and $r p l J / r p l K$ ) to provide complete information about the relative utility of the different assays.

\section{Materials and Methods}

Isolation of plant and ' $\mathrm{Ca}$. Liberibacter spp.' DNA. All isolates were propagated by grafting HLB-positive twigs (green cuttings) collected from PCR-positive citrus and were maintained in greenhouse-grown citrus plants. Grafted plants were periodically watered, fertilized, and monitored for 12 to 15 weeks under $50 \%$ shade cloth with 10 to $12 \mathrm{~h}$ daylight. Total DNA from HLB isolates was extracted using the DNeasy Plant Mini Kit (19) (Qiagen, Valencia, CA) from the petioles and midribs $(100 \mathrm{mg})$ of infected Citrus sinensis (sweet orange) leaves. Total DNA from PCR-positive Citrus sinensis infected with ' $\mathrm{Ca}$. Liberibacter asiaticus' (from Florida, Japan, Thailand, and Taiwan), ' $C a$. Liberibacter americanus' (from Brazil), and ' $\mathrm{Ca}$. Liberibacter africanus' (from South Africa) was obtained from the USDA-ARS collections in Beltsville and Fort Detrick, MD. DNA from Florida isolates of ' $\mathrm{C} a$. Liberibacter asiaticus' was obtained from greenhouse-grown HLBaffected plants at the University of Florida, Citrus Research and Education Center (CREC), Lake Alfred. DNA samples were stored at $-20^{\circ} \mathrm{C}$. The yield and purity of the DNA samples were estimated by measuring $\mathrm{OD}_{260}$ and $\mathrm{OD}_{260 / 280}$, respectively, with a NanoDrop Spectrophotometer ND-1000 (Wilmington, DE). DNA was extracted from ' $\mathrm{Ca}$. L. solanacearum' infected potatoes (United States), tomatoes (United States), and carrots (Norway and Sweden) that were maintained at both the USDA-ARS, Yakima Agricultural Research Laboratory, Wapato, WA, and the USDA-ARSFDWSRU quarantine facility in Fort Detrick, MD, using the CTAB method (27) or DNeasy Plant Mini Kit according to manufacturer specifications.

Isolation of psyllid DNA. Total DNA was isolated from single psyllids that fed on ' $\mathrm{Ca}$. Liberibacter asiaticus' infected citrus plants (previously confirmed by qPCR) and healthy plants using the DNeasy Blood and Tissue kit (Qiagen, Valencia, CA). Single psyllids were ground in phosphate buffer using a micro pestle, and DNA was extracted following the manufacturer's protocol. There were 20 extractions performed with single psyllids. The extracted DNA samples were stored at $-20^{\circ} \mathrm{C}$. DNA was used for $\mathrm{qPCR}$ for ' $\mathrm{C} a$. Liberibacter asiaticus' using $16 \mathrm{~S}$ rDNA primer and probe sets (19). Later, the same DNA samples were analyzed with degenerate genus-specific $(r p o B)$ and species-specific $(r p l J)$ primer/probe sets in qPCR assays. Each qPCR assay was repeated with two technical replicates. Total DNA was isolated from potato psyllids (Bactericera cockerelli) maintained at the USDA-ARS, Yakima Agricultural Research Laboratory, Wapato, WA using the CTAB method (27). There were 20 extractions performed with groups of 5 psyl-

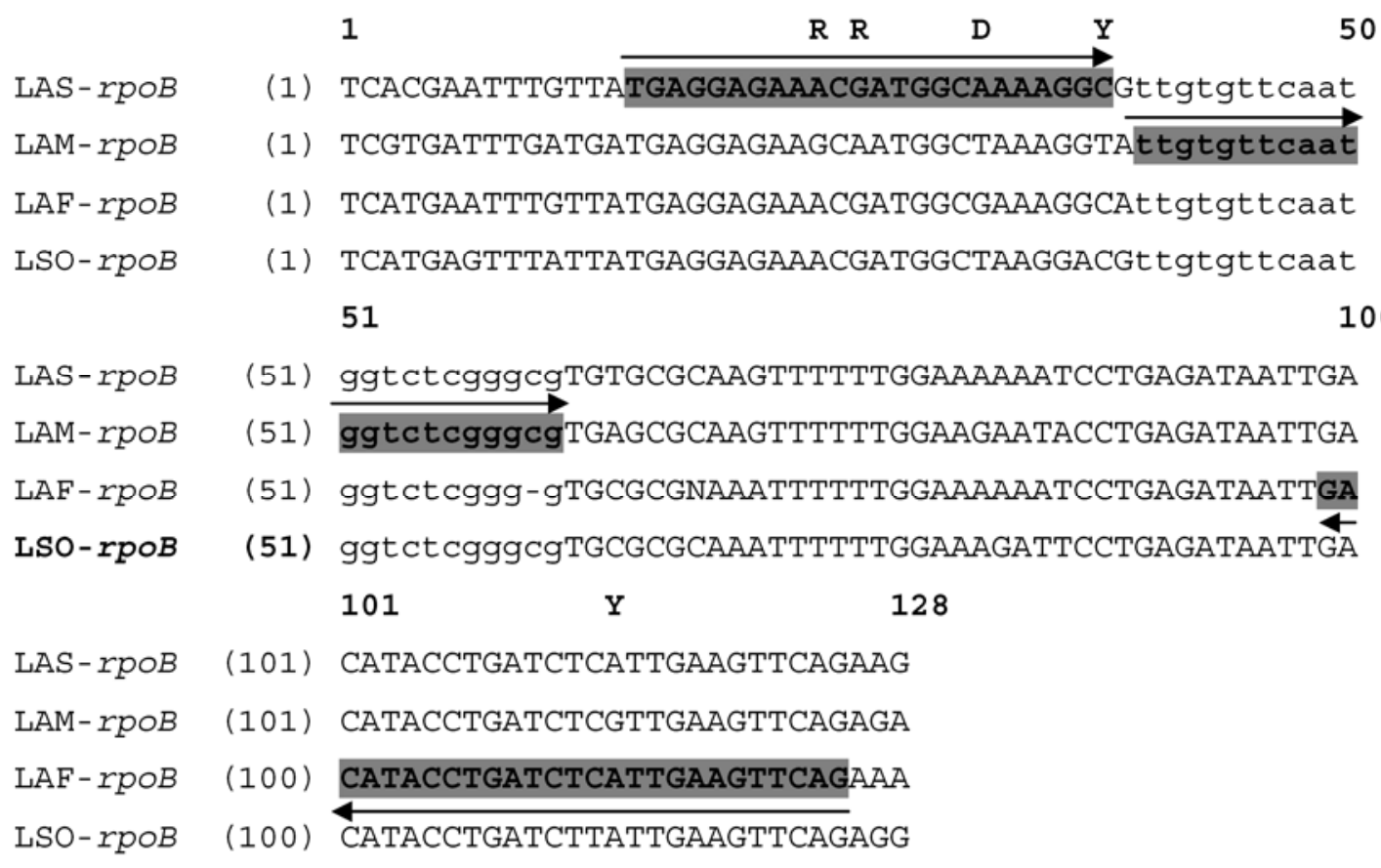

Fig. 1. Degenerate genus-specific primers and probe for amplification of the rpoB gene of 'Candidatus Liberibacter species'. Forward and reverse primer sequences are indicated with uppercase letters, and the probe sequence is indicated with lowercase letters (highlighted with shade and arrow for orientation). LAS, 'Ca. Liberibacter asiaticus'; LAM, 'Ca. Liberibacter americanus'; and LAF, 'Ca. Liberibacter africanus'. $R=A, G, Y=C, T, D=A, G, T$. 
lids/extraction. The extracted DNA samples were stored at $-20^{\circ} \mathrm{C}$. qPCR assays were performed with three technical replicates.

Design and synthesis of primers and probes. Partial sequences of the three ' $\mathrm{Ca}$. Liberibacter species' from infected citrus were obtained from GenBank (Accession numbers EU078703, EF122254, EF122255, and U09675). Multiple sequence alignments were performed using Vector NTI Advance 11 (Life Technologies, Carlsbad, CA) software. Primers and probes were designed using PrimerQuest software (Integrated DNA Technologies) to detect ' $C a$. Liberibacter species' at both the genus and species levels. Degenerate genus-specific $(r p o B)$ and species-specific $(r p l J / r p l K)$ primers were synthesized (Integrated DNA Technologies Inc., Coralville, IA). The nucleotide sequences of the primers and probes are shown in Figures 1 and 2. The probe for the genusspecific assay was labeled with FAM and BHQ1 dyes at the $5^{\prime}$ and $3^{\prime}$ ends, respectively. Probes for species-specific assays were labeled with TAMRA and BHQ2, Cy5 and BHQ2, FAM and BHQ1 at $5^{\prime}$ and $3^{\prime}$ ends for ' $\mathrm{Ca}$. Liberibacter africanus', ' $\mathrm{Ca}$. Liberibacter americanus', and ' $\mathrm{Ca}$. Liberibacter asiaticus', respectively. ' $\mathrm{Ca}$. Liberibacter solanacearum' specific primers and probe were tested according to Crosslin et al. (5).

Conventional PCR. ' $C a$. Liberibacter' DNA was amplified by conventional PCR with genus- and species-specific primers based on the $r p o B$ and $r p l J / r p l K$ gene regions, respectively, using ' $C a$. Liberibacter asiaticus', ' $\mathrm{Ca}$. Liberibacter americanus', and ' $\mathrm{Ca}$. Liberibacter africanus' isolates. The GoTaq Green Master Mix (Promega, Madison, WI) was used for the conventional PCR assay. The final composition of the PCR mix was $1 \times$ GoTaq Green Master Mix $(10 \mu \mathrm{l})$, forward and reverse primers (250 to $400 \mathrm{nM}$ each), $2 \mu \mathrm{l}$ DNA template, and nuclease free water to $20 \mu \mathrm{l}$. PCR was performed using the following parameters: one cycle at $94^{\circ} \mathrm{C}$ for 3 min; 35 cycles at $94^{\circ} \mathrm{C}$ for $30 \mathrm{~s}, 58^{\circ} \mathrm{C}$ for $30 \mathrm{~s}$, and $72^{\circ} \mathrm{C}$ for $45 \mathrm{~s}$; followed by one cycle at $72^{\circ} \mathrm{C}$ for $10 \mathrm{~min}$ in a thermal cycler (Model S1000 Thermal cycler, BIO-RAD, Hercules, CA). Amplified PCR products were analyzed using $1 \%$ agarose gels and stained with GelRed (Biotium, Hayward, CA). The PCR products

1

50

\begin{tabular}{|c|c|c|}
\hline LAS & (1) & GAATTAGTGTTGCGCAAATTAAAGATCTTCGGAAAAAGATGCGGGAAGCT \\
\hline LAM & (1) & GAATAAATGTTGCGCAAATCGGTAGTCTTAGAAAAAAGATGAAAgaagCg \\
\hline \multirow[t]{2}{*}{ LAF } & (1) & GTCCTGTTATTGGGCAGACTGGTATTTCTATTATGGCATTTTGTAAGGCG \\
\hline & & 51 \\
\hline LAS & $(51)$ & GGTGGAGGTGTAA - - -AAGTTGCCAAAAATCGTCTCGTCAAGATTGCTAT \\
\hline LAM & $(51)$ & ggaggatttgcta---aggttgtAAAGAACCGTCTTGTTAAGGTTGCTAT \\
\hline \multirow[t]{2}{*}{ LAF } & $(51)$ & TTTAATGCTGCAACCCAAGATATGGAAAAAGGTATCCCTA- - - TTCCAAC \\
\hline & & 101 \\
\hline LAS & $(98)$ & CCGTGATACTAGTATTAGAGGAATATCTGATCTTTTCGT-- - - - TGGGC \\
\hline LAM & $(98)$ & CAAAGACACCGATTTTCAGGGTATGTCTGATTTTTTTTC- - - - - - TGGGC \\
\hline \multirow[t]{2}{*}{ LAF } & $(98)$ & TACTGTAACTTGTTATAAAGACAAGTCTTTTGATTTTGCGATGAGTCAGC \\
\hline & & 151 \\
\hline LAS & $(142)$ & AGTCTCTAATTGTCTATTCGGATAGTCCTGTTATTGCTCCtaaatttcg \\
\hline LAM & $(142)$ & ААTСTTTGATAGTTTGTTCCAAAGATCCTGTTGCTGCACCCCAAATTTCT \\
\hline \multirow[t]{2}{*}{ LAF } & $(148)$ & CGCCTGTAAGTTTTTTTCTTAAAAAAGAGGCAGGTGTTAAGTCGGGATC- \\
\hline & & 201 \\
\hline LAS & $(192)$ & gttagctttcaaatgacaatA \\
\hline LAM & (192) & ГTTGCAAAAGAGAATGATCAATTTAAGATTATTG-GTGGCATTT \\
\hline \multirow[t]{2}{*}{ LAF } & (197) & - TAAGCTTCCTGGCAAGGAATCCTGTGGTTCTATTTCANGAGAAAAAGTT \\
\hline & & 251 \\
\hline LAS & $(241)$ & TAGAGAAGGGCGTCCTTAATCAAGATTCTATCAAGCAAATTGCTTCTTTA \\
\hline LAM & $(241)$ & TGGACAAGGGGATATTGGATAATGATGCCATAAAAGAGATAGCCTCTCTT \\
\hline \multirow[t]{2}{*}{ LAF } & $(246)$ & AAAAAAATTGCAGAAT- - - TAAAGATGC- - -AA- - GATA tgggtgctatt \\
\hline & & 301 \\
\hline LAS & (291) & CCCGATCTTGAGGGT-ATTCGAGC-TGGTATCA- - TAAGTGCTATCCA \\
\hline LAM & (291) & CCGAGCATTGATGTA-CTTCGTGC-TAGGATTT- - TAGGCTGTATTCA \\
\hline LAF & $(288)$ & AGCATGGTAGAAGGTTCGGCTTTTTCA \\
\hline
\end{tabular}

Fig. 2. Species-specific primers and probes for amplification of $r p / J / r p / K$ genes of 'Candidatus Liberibacter species' associated with citrus greening disease. Forward and reverse primer sequences are indicated with uppercase letters, and probe sequences are indicated with lowercase letters (highlighted with shade; italics and arrow for orientation). LAS, 'Ca. Liberibacter asiaticus'; LAM, 'Ca. Liberibacter americanus'; and LAF, 'Ca. Liberibacter africanus'. 
Table 1. Standard curve obtained in simplex qPCR with SYBR Green I dye and TaqMan probe assays utilizing primers and probes from the $r p o B$ and $r p l J / r p l K$ regions

\begin{tabular}{|c|c|c|c|c|c|c|c|c|c|c|c|c|}
\hline \multirow{4}{*}{$\begin{array}{l}\text { 'Candidatus Liberibacter } \\
\text { species' }\end{array}$} & \multicolumn{12}{|c|}{ Simplex qPCR assay } \\
\hline & \multicolumn{6}{|c|}{$\begin{array}{l}\text { Standard curve obtained with primers and probes } \\
\text { from the rpo } B^{\mathrm{a}} \text { region }\end{array}$} & \multicolumn{6}{|c|}{$\begin{array}{l}\text { Standard curve obtained with species-specific } \\
\text { primers and probes from the } r p l J / r p l K^{b} \text { regions }\end{array}$} \\
\hline & \multicolumn{3}{|c|}{ SYBR Green I dye } & \multicolumn{3}{|c|}{ TaqMan } & \multicolumn{3}{|c|}{ SYBR Green I dye } & \multicolumn{3}{|c|}{ TaqMan } \\
\hline & Slope & SE & $R^{2}$ & Slope & SE & $R^{2}$ & Slope & SE & $R^{2}$ & Slope & SE & $R^{2}$ \\
\hline 'Ca. L. asiaticus' (LAS) & $\begin{array}{c}-3.879 x \\
+39.47\end{array}$ & $\begin{array}{l}0.048 \\
0.216\end{array}$ & 0.997 & $\begin{array}{c}-3.836 \mathrm{x} \\
+39.46\end{array}$ & $\begin{array}{l}0.021 \\
0.097\end{array}$ & 0.999 & $\begin{array}{c}-3.637 x \\
+36.26\end{array}$ & $\begin{array}{l}0.087 \\
0.389\end{array}$ & 0.989 & $\begin{array}{l}-3.913 x \\
+41.66\end{array}$ & $\begin{array}{l}0.058 \\
0.259\end{array}$ & 0.995 \\
\hline 'Ca. L. americanus' (LAM) & $\begin{array}{c}-3.862 \mathrm{x} \\
+38.72\end{array}$ & $\begin{array}{l}0.032 \\
0.146\end{array}$ & 0.998 & $\begin{array}{c}-3.987 \mathrm{x} \\
+40.17\end{array}$ & $\begin{array}{l}0.032 \\
0.147\end{array}$ & 0.998 & $\begin{array}{c}-3.654 x \\
+36.27\end{array}$ & $\begin{array}{l}0.036 \\
0.163\end{array}$ & 0.998 & $\begin{array}{l}-3.778 \mathrm{x} \\
+40.24\end{array}$ & $\begin{array}{l}0.031 \\
0.138\end{array}$ & 0.998 \\
\hline 'Ca. L. africanus' (LAF) & $\begin{array}{c}-3.907 x \\
+38.65\end{array}$ & $\begin{array}{l}0.036 \\
0.161\end{array}$ & 0.998 & $\begin{array}{l}-4.001 \mathrm{x} \\
+40.33\end{array}$ & $\begin{array}{l}0.038 \\
0.173\end{array}$ & 0.998 & $\begin{array}{c}-3.679 \mathrm{x} \\
+36.01\end{array}$ & $\begin{array}{l}0.036 \\
0.161\end{array}$ & 0.998 & $\begin{array}{l}-3.767 x \\
+40.48\end{array}$ & $\begin{array}{l}0.048 \\
0.217\end{array}$ & 0.996 \\
\hline
\end{tabular}

${ }^{\text {a }}$ LAS, plasmid DNA diluted from $4.14 \times 10^{7}$ to $10^{1}$ molecules $/ \mu \mathrm{l}$; LAM, plasmid DNA diluted from $3.9 \times 10^{7}$ to $10^{1}$ molecules $/ \mu 1$; and LAF, plasmid DNA diluted from $4.55 \times 10^{7}$ to $10^{1}$ molecules/ $\mu$ l (genus specific).

${ }^{\text {b }}$ LAS, plasmid DNA diluted from $3.27 \times 10^{7}$ to $10^{1}$ molecules $/ \mu$; LAM, plasmid DNA diluted from $2.71 \times 10^{7}$ to $10^{1}$ molecules $/ \mu \mathrm{l}$; and LAF, plasmid DNA diluted from $4.26 \times 10^{7}$ to $10^{1}$ molecules $/ \mu \mathrm{l}$ (species specific).

from different ' $\mathrm{Ca}$. Liberibacter species' were purified using QIAquick PCR Purification Kit (Qiagen, Valencia, CA). PCR products were then cloned with the pGEM-T Easy Vector System according to manufacturer protocols. Positive clones were sequenced (five clones for each isolates) for confirmation of their identity at the Interdisciplinary Center for Biotechnology Research (ICBR), University of Florida, Gainesville. The number of plasmid molecules was calculated (plasmid length in base pairs $\times 650 \mathrm{D} / \mathrm{bp}$ $=6.022 \times 10^{23}$ molecules $/$ mole) . Clones confirmed by sequencing were used to determine the sensitivity of the PCR assay. Plasmid DNA dilutions from $4.14 \times 10^{7}$ to $10^{1}, 3.9 \times 10^{7}$ to $10^{1}, 4.55 \times 10^{7}$ to $10^{1}$ molecules/ $\mu$ l for ' $C a$. Liberibacter asiaticus', ' $C a$. Liberibacter americanus', and ' $C a$. Liberibacter africanus', respectively, were used for genus-specific assay, and plasmid dilutions to $3.27 \times$ $10^{7}$ to $10^{1}, 2.71 \times 10^{7}$ to $10^{1}, 4.26 \times 10^{7}$ to $10^{1}$ molecules/ $\mu l$ for ' $C a$. Liberibacter asiaticus', ' $C a$. Liberibacter americanus', and ' $C a$. Liberibacter africanus', respectively, were used for speciesspecific assays. The specificity of primer sets was tested with the three ' $\mathrm{Ca}$. Liberibacter species' from citrus and against eight endophytic bacteria (Paenibacillus glucanolyticus, Microbacterium sp., Pantoea agglomerans, Pseudomonas sp., Enterobacter cloacae, Rhizobium sp., Agrobacterium tumefaciens, Sinorhizobium sp.) and two citrus canker pathogens (Xanthomonas axonopodis pv. citri 306 and Xanthomonas axonopodis pv. citri $\mathrm{A}^{\mathrm{W}}$, provided by $\mathrm{N}$. Wang and P. Trivedi, University of Florida). The genus-specific primer set was also tested against positive plant and psyllid samples that were tested previously with the $16 \mathrm{~S}$ primers and probe set (19). Extracts of healthy plants and water only (nontemplate control) samples were used as negative controls. A sequence confirmed plasmid DNA sample was used to estimate copy number of 'Ca. Liberibacter solanacearum'.

Simplex and multiplex real-time PCR assay. PCR products were purified and then cloned in the pGEM-T Easy Vector. The concentrations of cloned and sequence confirmed plasmid DNA samples were measured, and target copy numbers were calculated as above. Reaction optimization to standardize conditions was carried out with 10 -fold dilutions in sterile distilled water $\left(10^{7}\right.$ to $10^{1}$ ) utilizing sequence confirmed plasmid DNA samples. Simplex and multiplex PCR assays using both SYBR Green I or TaqMan probes for quantification were completed. Results were compared with the sensitivity of conventional PCR. qPCR assays were performed on an Applied Biosystems 7500 PCR instrument (Life Technologies). The TaqMan Universal PCR Master Mix (Life Technologies) was used for the qPCR assay. The final concentration of qPCR mix contained 1× TaqMan Universal PCR Master Mix $(10 \mu \mathrm{l})$, forward and reverse primers (250 to $800 \mathrm{nM}$ each), probe ( 150 to $400 \mathrm{nM}), 2 \mu \mathrm{l}$ DNA (120 to $155 \mathrm{ng} / \mu \mathrm{l})$ template, and nuclease free water to $20 \mu \mathrm{l}$. The qPCR assay consisted of $2 \mathrm{~min}$ incubation at $50^{\circ} \mathrm{C}$ followed by $10 \mathrm{~min}$ incubation at $95^{\circ} \mathrm{C}$ and 40 cycles at $95^{\circ} \mathrm{C}$ for $15 \mathrm{~s}$ and $60^{\circ} \mathrm{C}$ for $1 \mathrm{~min}$. Data were analyzed using the Applied Biosystems software Version 1.4.0. Simplex PCR assays were conducted and summarized (Table 1). Three simplex quantitative PCR assays were then combined in multiplex reactions and optimized. For standard curve analysis, there were six technical replicates collected from two biological experiments that had three technical replicates each. Healthy citrus plant material and water (nontemplate control) samples were used as negative control in qPCR assays.

Comparison of three primer and probe sets for diagnosis of HLB. The concentrations of genus- and species-specific primers and probes were optimized with DNA of ' $\mathrm{Ca}$. Liberibacter spp.' from, Brazil, Florida, Japan, Taiwan, Thailand, and South Africa as well as with DNA samples from psyllids that fed on ' $\mathrm{Ca}$. Liberibacter asiaticus' infected plants. Comparisons were made with the $16 S$ rDNA primer and probe sets (19) widely used for the detection of the three citrus ' $\mathrm{Ca}$. Liberibacter spp.' All assays employed the qPCR protocol mentioned above. To finally validate the degenerate genus-specific primers and probe, they were tested against ' $\mathrm{Ca}$. Liberibacter solanacearum' in extracts of diseased potato (United States), tomato (United States), and carrot (Norway and Sweden), in addition to extracts of potato psyllids. The qPCR assay primers and probes were validated with the three ' $\mathrm{Ca}$. Liberibacter species' from citrus and also were tested for specificity against the bacterial endophytes listed above. Comparisons of the $16 \mathrm{~S}$ rDNA assay with the $r p o B$ and the $(r p l J / r p l K)$ assays were repeated with two technical replicates using plants known to be HLB positive. Data were analyzed by analysis of variance (ANOVA; Tukey's HSD) for significance at the $5 \%$ level. The hypothesis evaluated by the ANOVA was that one of the sets of primers would provide better sensitivity (lower quantification cycle [Cq]) in the assay.

\section{Results}

DNA isolation and conventional PCR. A good yield of total DNA (80.6 to $94.8 \mathrm{ng} / \mu \mathrm{l}$ ) was obtained from healthy and infected citrus tissue using the Qiagen DNeasy Plant Mini Kit. Conventional PCR assays were performed with both genus- $($ rpoB) and species-specific $(r p l J / r p l K)$ primers. The expected 111-bp PCR amplicon for the genus-specific assay and the 182-bp, 174-bp, and 157-bp amplicons for ' $\mathrm{Ca}$. Liberibacter asiaticus', ' $\mathrm{C} a$. Liberibacter americanus', and ' $\mathrm{Ca}$. Liberibacter africanus' species-specific assays, respectively, were obtained. The PCR products were purified and then cloned in the pGEM-T Easy Vector. Sequence-confirmed clones were used for assay standardization and sensitivity studies. Amplicons of the expected sizes were produced (Fig. 3). The degenerate genus-specific primers at concentrations of $400 \mathrm{nM}$ each were able to successfully amplify target DNA cloned in plasmids at concentrations of about 4,000 target molecules per $\mu \mathrm{l}(4.14$ $\times 10^{3}, 3.9 \times 10^{3}$, and $4.55 \times 10^{3}$ molecules $/ \mu$ l for ' $\mathrm{Ca}$. Liberibacter asiaticus', ' $C a$. Liberibacter americanus' and ' $C a$. Liberibacter africanus', respectively). Species-specific primer sets at a concen- 


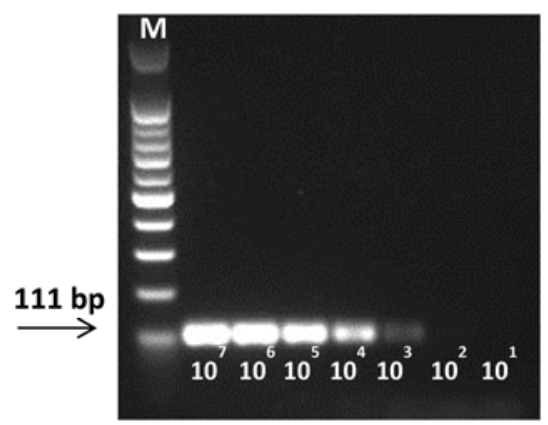

'Ca. Liberibacter asiaticus'

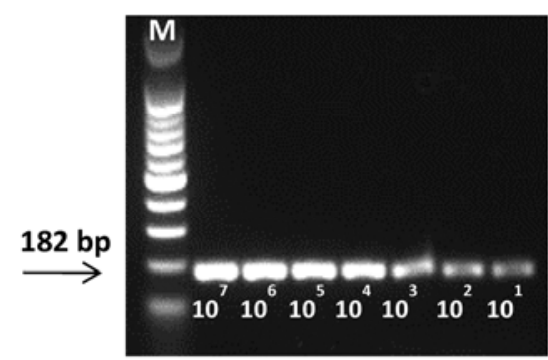

'Ca. Liberibacter asiaticus'

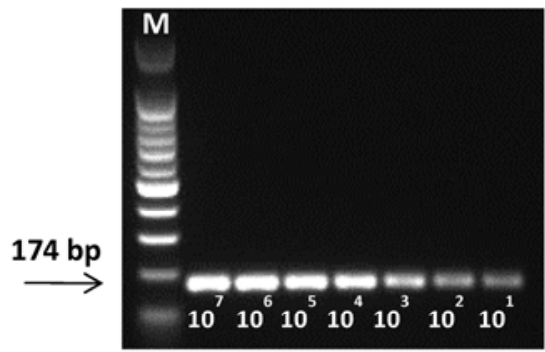

'Ca. Liberibacter americanus'

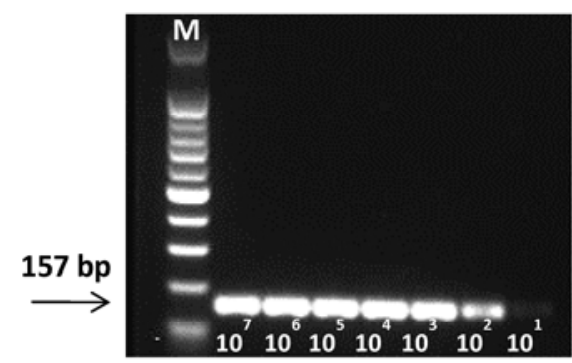

'Ca. Liberibacter africanus'

Fig. 3. Conventional polymerase chain reaction assay with genus-(rpoB*-upper panel) and species-(rp/J/rp/K**-lower panels) specific primers using plasmid DNA diluted from $10^{7}$ to $10^{1}$ for detection of 'Candidatus Liberibacter asiaticus', 'Ca. Liberibacter americanus', and 'Ca. Liberibacter africanus'. $M=100-b p$ molecular marker.

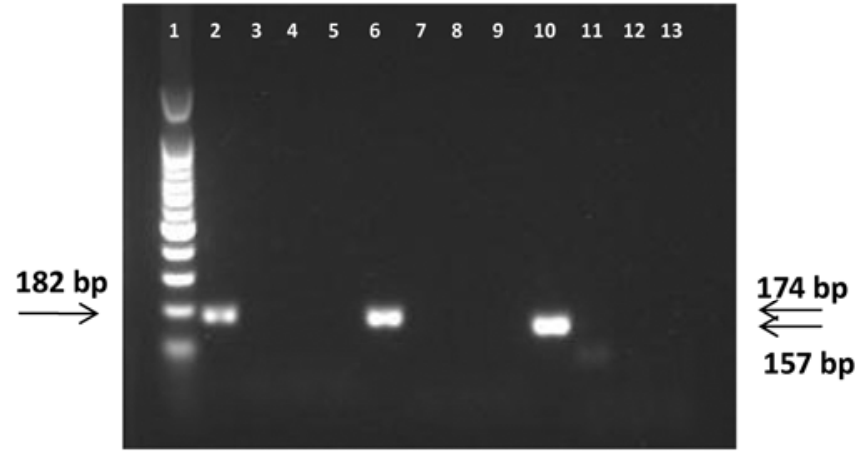

Fig. 4. Conventional polymerase chain reaction assay with species- $(r p / J / r p / K)$ specific primer sets using positive plant DNA samples from different geographical areas for specificity of 'Candidatus Liberibacter asiaticus' (LAS, $182 \mathrm{bp),} \mathrm{'Ca.}$ Liberibacter americanus' (LAM, 174 bp), and 'Ca. Liberibacter africanus' (LAF, 157 bp). Lane 1, 100-bp marker; lane 2, LAS sample from Taiwan (D495); lane 3, LAM sample from Brazil (B427); lane 4, LAF sample from South Africa (HMV5); lane 5, water sample (nontemplate control); lane 6, LAM sample from Brazil (B427); lane 7, LAS sample from Taiwan (D495); lane 8, LAF sample from South Africa (HMV5); lane 9, water sample (nontemplate control); lane 10, LAF sample from South Africa (HMV5); lane 11, LAS sample from Taiwan (D495); lane 12, LAM sample from Brazil (B427); lane 13, water sample (nontemplate control).

tration of $250 \mathrm{nM}$ each were able to specifically detect the DNA of ' $\mathrm{Ca}$. Liberibacter species' at concentrations of about 40 target molecules per $\mu \mathrm{l}\left(3.27 \times 10^{1}, 2.71 \times 10^{1}\right.$, and $4.26 \times 10^{1}$ molecules/ $\mu$ l for ' $C a$. Liberibacter asiaticus', ' $C a$. Liberibacter americanus', and ' $\mathrm{Ca}$. Liberibacter africanus', respectively) (Fig. 3). No nonspecific reactions were observed and no cross reactions were found among the species-specific primers with appropriate plant samples (Fig. 4). No reaction products were produced with DNA samples of the eight bacterial endophytes or with the two citrus canker bacterial isolates. In addition, no products were produced with water (nontemplate) controls (Fig. 4). The degenerate genusspecific primer set produced expected amplicons from ' $\mathrm{Ca}$. Liberibacter asiaticus' positive plant and psyllid samples (Fig. 5). No reaction products were produced with healthy citrus, psyllid, and water (nontemplate control) samples (Fig. 5).

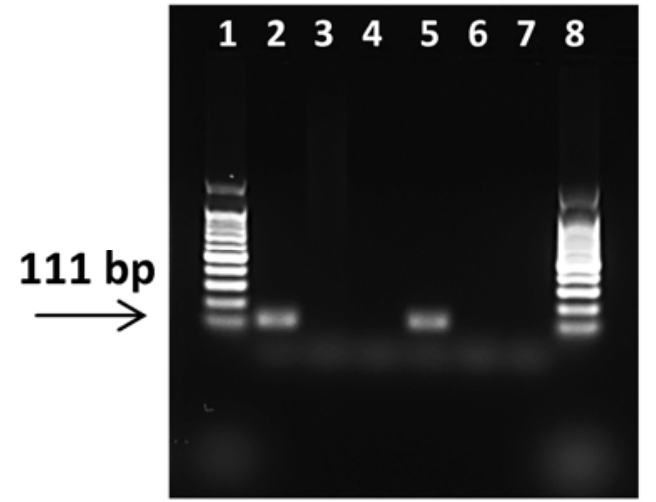

Fig. 5. Conventional polymerase chain reaction assay with genus- $(r p o B)$ specific primers using both plant and psyllid DNA samples for detection of 'Candidatus Liberibacter asiaticus' (LAS). Lanes 1 and 8, 100-bp marker; lane 2, LAS-positive citrus sample from Florida; lane 3 , healthy plant sample; lane 4, water sample (nontemplate control); lane 5, LAS-positive psyllid sample; lane 6, healthy psyllid sample; lane 7, water sample (nontemplate control).

Standard curves with SYBR Green I and TaqMan probes. Simplex qPCR was performed with $r p o B$ primers using SYBR Green I and the TaqMan probe formats. Diluted plasmid DNA $\left(4.14 \times 10^{7}\right.$ to $10^{1}, 3.9 \times 10^{7}$ to $10^{1}, 4.55 \times 10^{7}$ to $10^{1}$ molecules $/ \mu l$ for ' $\mathrm{Ca}$. Liberibacter asiaticus', ' $\mathrm{Ca}$. Liberibacter americanus', and ' $\mathrm{Ca}$. Liberibacter africanus', respectively) containing target inserts was used to prepare a standard curve. There were no differences in the Cq value for simplex qPCR assays with either SYBR Green I or TaqMan for any of the three Liberibacter species tested (Table 1). Regression analysis was used to calculate standard curves with slopes of -4.000 to -3.836 and $R^{2}=0.998-0.999$ for TaqMan assays and -3.907 to -3.862 and $R^{2}=0.997-0.998$ for SYBR Green I assays. The optimized concentrations of the degenerate genusspecific $(r p o B)$ primers $(400 \mathrm{nM})$ and probe $(200 \mathrm{nM})$ successfully detected DNA from all three ' $\mathrm{Ca}$. Liberibacter species' when tested separately in simplex qPCR. Diluted plasmid DNA $\left(3.27 \times 10^{7}\right.$ to $10^{1}, 2.71 \times 10^{7}$ to $10^{1}, 4.26 \times 10^{7}$ to $10^{1}$ molecules/ $\mu$ l for ' $\mathrm{Ca}$. Liberibacter asiaticus', 'Ca . Liberibacter americanus', and ' $C a$. Li- 
beribacter africanus', respectively) was used to prepare a standard curve for species-specific primer and probe sets. A standard curve for the simplex qPCR with specific primer and probe sets from the $(r p l J / r p l K)$ gene regions also was obtained using SYBR Green I. There was a difference in $\mathrm{Cq}$ values between the two assay formats, but there was no difference in the endpoint dilution between SYBR Green I and primer/probe sets in TaqMan assays (Table 1). The slope and $R^{2}$ ranges of the TaqMan assays were -3.913 to -3.767 with $R^{2}=0.995-0.998$, whereas the slope and $R^{2}$ values of SYBR Green I assays were -3.679 to -3.637 with $R^{2}=0.989-$ 0.998 . The species-specific primers used at $250 \mathrm{nM}$ each and the probe at a concentration of $150 \mathrm{nM}$ successfully detected all three species in simplex qPCR assays. The standard curve obtained in the multiplex TaqMan qPCR assay with the rplJ/rplK specific primers and probes also produced similar results to the species-specific simplex qPCR assay (Fig. 6). There was no difference between the simplex and multiplex assays in terms of the Cq values. In the multiplex PCR assay, the species-specific primers and probe concentrations were increased to 800 and $400 \mathrm{nM}$, respectively, for ' $\mathrm{Ca}$. Liberibacter asiaticus' and ' $\mathrm{Ca}$. Liberibacter americanus', and 600 and $300 \mathrm{nM}$ for ' $C a$. Liberibacter africanus'. No cross-amplifications with the three citrus ' $\mathrm{Ca}$. Liberibacter species' were found using the species-specific primers in either SYBR Green I or TaqMan assay formats. In addition, no amplifications were observed with DNA from the bacterial

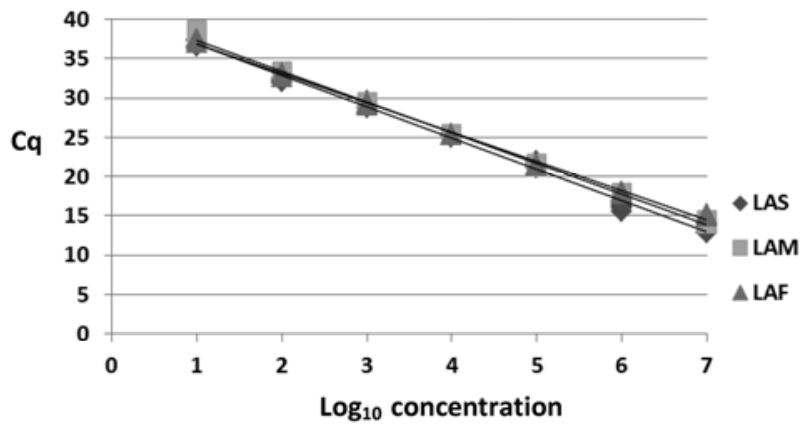

$$
\begin{array}{ccc}
\text { LAS } y=-3.9819 x+40.843 & \text { LAM } y=-3.9106 x+41.266 & \text { LAF } y=-3.7328 x+40.535 \\
R^{2}=0.9932 & R^{2}=0.9975 & R^{2}=0.9971
\end{array}
$$

Fig. 6. Standard curve obtained in multiplex $q P C R$ with species-specific primers and probe (TaqMan assay) from the $r p / J / r p / K$ regions using plasmid DNA diluted from $10^{7}$ to $10^{1}$ for detection of 'Candidatus Liberibacter asiaticus' (LAS), 'Ca. Liberibacter americanus' (LAM), and 'Ca. Liberibacter africanus' (LAF). endophytes or other bacterial DNA samples or healthy plant/ water samples (data not shown).

Comparison of the three primers and probe sets in qPCR. The primers and probe sets (from the rpoB and $r p l J / r p l K$ gene sequences) used in this study successfully detected ' $\mathrm{Ca}$. Liberibacter asiaticus', ' $\mathrm{Ca}$. Liberibacter americanus', and ' $\mathrm{Ca}$. Liberibacter africanus' in qPCR, as did assays with the $16 \mathrm{~S}$ rDNA primers and probe (19). The $\mathrm{Cq}$ values for $r p o B$ (genus-specific) and $r p l J$ (species-specific) were consistently about 3 to 4 cycles higher and significantly different than the $\mathrm{Cq}$ values for $16 \mathrm{~S}$ rDNA primers and probe for detection of ' $\mathrm{Ca}$. Liberibacter asiaticus' (Fig. 7). However, the $\mathrm{Cq}$ values were generally not significantly different between the $r p o B$ and $r p l J$ primers and probe sets for detection of 'Ca. Liberibacter asiaticus' (Fig. 7). The Cq values were lower with the $16 \mathrm{~S}$ rDNA primers and probe used for detection of ' $\mathrm{Ca}$. Liberibacter americanus' and significantly different from the rpoB and rplJ primers and probe sets (Fig. 8). The Cq values for the $r p o B$ primers and probe were lower (more sensitive) than the values for the $r p l J$ primers and probe for ' $\mathrm{Ca}$. Liberibacter americanus'. All three primers and probe sets for ' $\mathrm{Ca}$. Liberibacter africanus' produced similar results (Fig. 8). The degenerate genusspecific rpoB primers and probe showed lower $\mathrm{Cq}$ values than the species-specific primers and probe $(r p l K)$ for ' $\mathrm{Ca}$. Liberibacter africanus'. Comparison of the three primers and probe sets $(16 \mathrm{~S}$ rDNA/rpoB/rplJ) for the detection of ' $\mathrm{Ca}$. Liberibacter asiaticus' in single psyllids showed significantly lower $\mathrm{Cq}$ values with the $16 S$ rDNA primers and probe followed by $r p o B$ and $r p l J$ primers and probe sets (Fig. 9). The degenerate genus-specific rpoB primers and probe assay was also able to detect ' $\mathrm{Ca}$. Liberibacter solanacearum' in extracts from tomato and carrot, but not potato plants, possibly due to a low level of bacteria present in the potato samples (Table 2). However, 'Ca. Liberibacter solanacearum' was successfully detected in psyllids from an infectious potato psyllid colony. The $\mathrm{Cq}$ values of ' $\mathrm{Ca}$. Liberibacter solanacearum' specific qPCR results were compared with degenerate genus-specific $r p o B$ primers and probe. qPCR results for ' $\mathrm{Ca}$. Liberibacter solanacearum' infected tomato and carrot samples differed by approximately 10 and $4 \mathrm{Cq}$ values (Table 2).

\section{Discussion}

qPCR assays based on 16S RNA genes are widely used for the species-specific detection of ' $\mathrm{Ca}$. Liberibacter asiaticus' and the other species of Liberibacter associated with citrus. However, these assays cannot be multiplexed and were developed before the potential host range of ' $\mathrm{Ca}$. Liberibacter spp.' was fully appreciated (19).

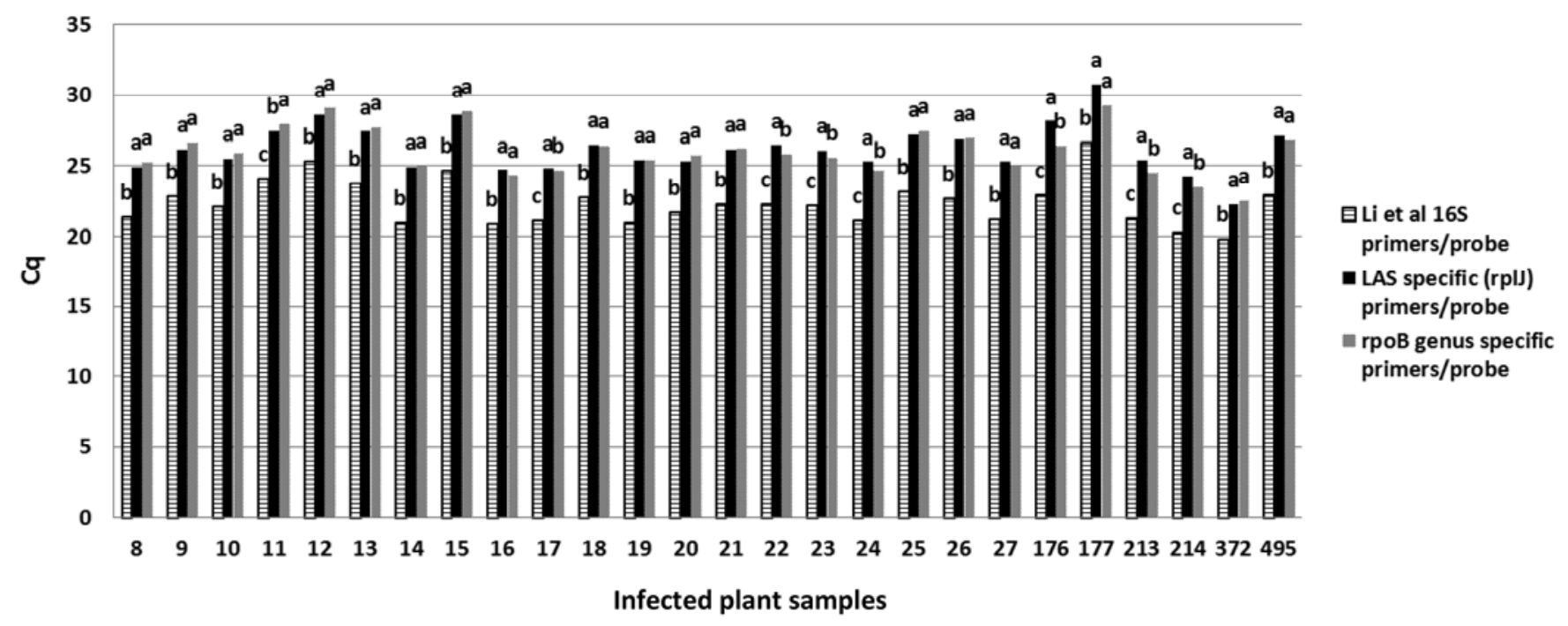

Fig. 7. Comparison of $\mathrm{Cq}$ values obtained using $16 \mathrm{~S}$ rDNA specific to that of 'Candidatus Liberibacter asiaticus' (LAS), LAS-specific ( $r p / J)$ and genus-specific rpoB primers and probes for detection of LAS. Samples 8 to 27 are from Florida, 176 and 177 are from Japan, 213 and 214 are from Thailand, and 372 and 495 are from Taiwan. Data were analyzed by analysis of variance (ANOVA) and Tukey's test at the $5 \%$ level of significance. 
In this study, a $r p o B$ based primer and probe assay was developed for use in qPCR for the detection of the genus ' $\mathrm{Ca}$. Liberibacter'. In addition, identification at the level of species was done with several novel multiplex qPCR assays utilizing ( $r p l J / r p l K$ ) primers and probe sets. The presence of three different hybridization probes, one for each ' $\mathrm{Ca}$. Liberibacter sp.' allows for the first time, multiplexed species-specific identification of ' $\mathrm{Ca}$. Liberibacter spp.' In this study, we utilized the $r p o B$ gene region for the development of primers and probe for the detection of ' $\mathrm{Ca}$. Liberibacter spp.' at the genus level. The rplJ/rplK genes encode the L10 and L11 proteins which are components of the 50S subunit of the ribosome, and each is also present in a single copy per genome. We used these sequences for the development of primers and probes for the simultaneous detection and identification of ' $\mathrm{Ca}$. Liberibacter' at the species level. Recently, the sequence of $r p l J$ was used for characterization of the diversity of ' $\mathrm{Ca}$. Liberibacter species'/ strains in Kenya (23).

' $\mathrm{Ca}$. Liberibacter' DNA was amplified by conventional PCR assays using plasmid DNA templates and displayed specific gene products corresponding to their primer pairs. The genus-specific assay was capable of detecting target DNA from ' $\mathrm{Ca}$. Liberibacter spp.' when more than 4,000 target molecules were present in the assay mixture, whereas the species-specific assay was capable of detecting target DNA when about 40 target molecules were present in the assay mixture. Neither assay showed any cross reactivity, nor was there amplification of DNA from bacterial endophytes or other bacterial species. In qPCR, the standard curve generated from the 10 -fold serial dilution of each species tested and the derived correlation coefficients demonstrated a good correlation between the $\mathrm{Cq}$ values and template concentrations as well as reproducibility.

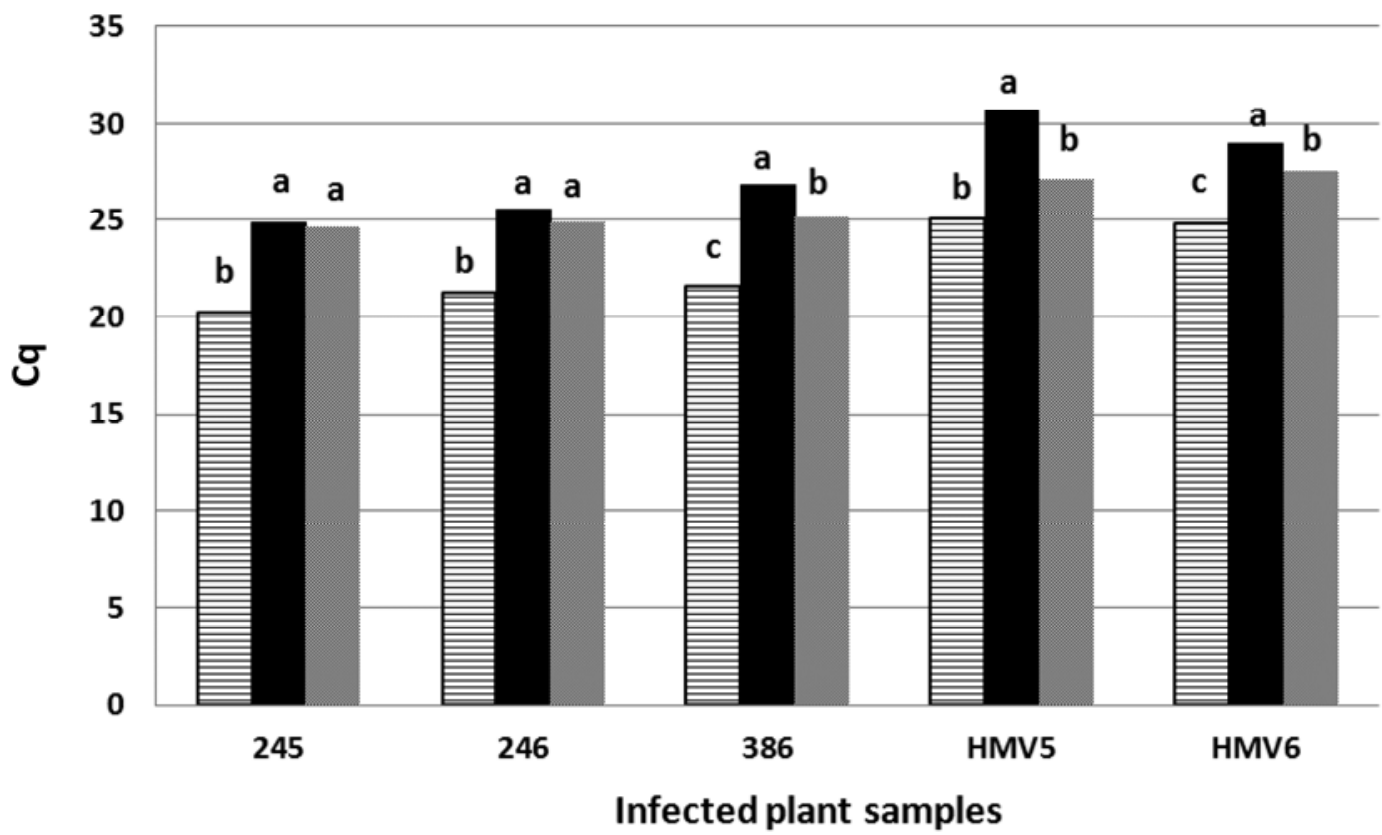

日 Li et al 16S primers/probe

- LAM/LAF specific (rplJ/rplK) primers/probe

rpoB genus specific primers/probe

Fig. 8. Comparison of $\mathrm{Cq}$ values obtained using $16 \mathrm{~S}$ rDNA specific to that of 'Candidatus Liberibacter americanus' (LAM), LAM-specific (rp/J) and genus-specific rpoB primers and probes for detection of LAM. Comparison of Cq values obtained using $16 S$ rDNA specific to that of 'Ca. Liberibacter africanus' (LAF), LAF specific (rp/K) and rpoB primers and probes for detection of LAF. Samples 245, 246, and 386 are from Brazil. Samples HMV5 and HMV6 are from South Africa. Data were analyzed by analysis of variance (ANOVA) and Tukey's test at the $5 \%$ level of significance.

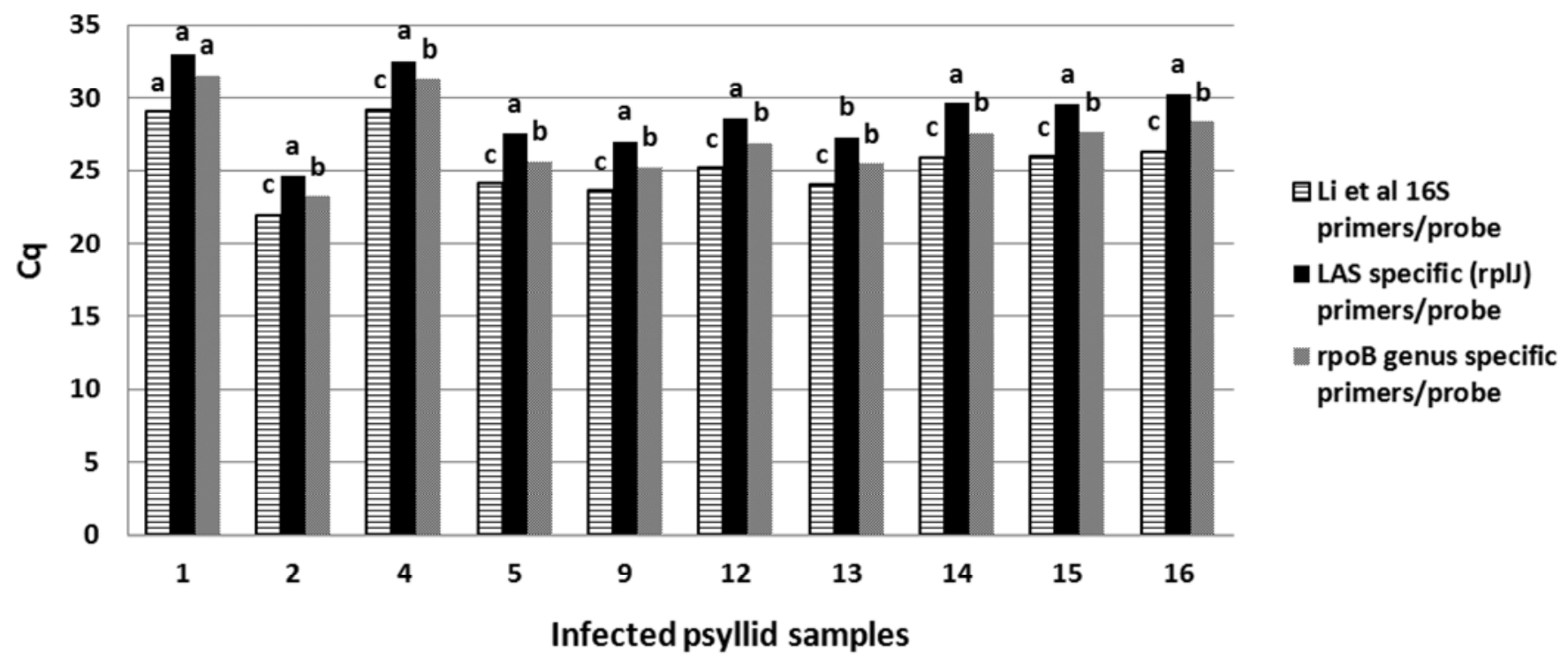

Fig. 9. Comparison of $\mathrm{Cq}$ values obtained using $16 \mathrm{~S}$ rDNA specific to that of 'Candidatus Liberibacter asiaticus' (LAS), LAS-specific (rp/J) and rpoB primers and probes for detection of LAS in psyllids. Samples 1 to 16 are from psyllids that fed on LAS-infected plants. Data were analyzed by analysis of variance (ANOVA) and Tukey's test at the $5 \%$ level of significance. 
Standard curve analysis of the genus-specific assays (rpoB) showed no difference in terms of $\mathrm{Cq}$ values between qPCR assays run in either the SYBR Green I or TaqMan formats. The speciesspecific $(r p l J / r p l K)$ assay was more sensitive when run in the SYBR Green I than in the TaqMan format. The Cq values were not different when the assay was run in simplex or multiplex formats, demonstrating that the simultaneous amplification and detection of three products did not interfere with each other.

In order to compare the sensitivity of the new assays to a standard assay, the $\mathrm{Cq}$ values of the $16 \mathrm{~S}$ rDNA $(19,20), \operatorname{rpoB}$, and $r p l J / r p l K$ primers and probes for detection of ' $\mathrm{Ca}$. Liberibacter spp.' were compared. The standard $16 \mathrm{~S}$ rDNA target gave significantly lower $\mathrm{Cq}$ values compared with the $r p o B$ and $r p l J / r p l K$ gene targets for ' $\mathrm{Ca}$. Liberibacter spp.' This was probably due to the presence of three copies of the $16 \mathrm{~S}$ rDNA target in ' $\mathrm{Ca}$. Liberibacter spp.' $(9,16)$. As discussed above, the $r p o B$ and $r p l J / r p l K$ genes are single-copy targets, and thus a higher $\mathrm{Cq}$ is expected. The genus-specific system also used degenerate primers which may give higher $\mathrm{Cq}$ values (less sensitive) when compared with sequencespecific primer pairs due to mismatch pairing. The advantage of assays such as these based on protein coding genes is improved specificity. The $r p o B$ primers and probe set gave significantly better sensitivity (lower $\mathrm{Cq}$ ) compared to $\mathrm{rplJ} / \mathrm{rplK}$ primers and probe sets in some geographical samples tested for " $\mathrm{Ca}$. Liberibacter spp.' Similar results were observed in extracts of psyllids for detection of ' $\mathrm{Ca}$. Liberibacter asiaticus'. The $r p o B$ primer and probe set also detected ' $\mathrm{Ca}$. Liberibacter solanacearum' from tomato, carrot, and psyllids in the qPCR assay and thus showed the broad application of the genus-specific Liberibacter primers. ' $C a$. Liberibacter solanacearum' was not detected in extracts of infected potatoes, perhaps due to low populations of the bacterium in planta and the efficiency of the degenerate primers. However, these factors did not prevent the detection of ' $\mathrm{Ca}$. Liberibacter solanacearum' in potato psyllids that fed on affected potato plants. The rpoB-and $r p l J / r p l K$-based assays did not amplify DNA from healthy hosts,
Liberibacter-free psyllids, or common bacterial endophytes. This is another favorable feature of this set of assays, since the $16 \mathrm{~S}$ rDNAbased assay has been shown to generate $\mathrm{Cq}$ values in the upper $30 \mathrm{~s}$ for a number of healthy controls (7).

In conclusion, this study shows that $r p o B$ is a good molecular marker for the detection of Liberibacters, and is complementary to $16 S$ rDNA. Primers and probe from the $r p o B$ region were successfully designed, standardized, and used for the detection of all ' $\mathrm{Ca}$. Liberibacter spp.' from citrus at the genus level. In addition, the $r p o B$ assay also detected ' $C a$. Liberibacter solanacearum' from tomatoes, carrots, and their respective psyllid vectors, further demonstrating the assay's utility for detection and identification at the genus level. If the current described ' $\mathrm{Ca}$. Liberibacters' are a subset of a larger population that exists in nature, additional ' $\mathrm{Ca}$. Liberibacter species' will be found using the $r p o B$ primers. Thus, amplicons produced by our degenerate genus-specific primers may reveal currently unknown ' $\mathrm{C} a$. Liberibacter species' and should have utility in both research and regulatory arenas. This genus level assay is nicely complemented by an assay based on primers and probe for the $r p l J / r p l K$ region. This assay was successfully designed and validated for species-specific detection of the three ' $\mathrm{Ca}$. Liberibacter spp.' from citrus. This $r p l J / r p l K$ assay also was validated in a multiplex qPCR assay for species-specific identification of the citrus ' $C a$. Liberibacter spp.' These gene targets, like the widely used $16 \mathrm{~S}$ rDNA amplification target, are members of the conserved core set of bacterial genes. Our assays provide a useful complement to the existing $16 \mathrm{~S}$ rDNA based assays and provide new capabilities to identify ' $\mathrm{Ca}$. Liberibacter spp.' at the level of genus as well as simultaneous and multiplexed identification at the species level. The development of a multiplex assay for citrus species of Liberibacter is important in view of the current rapid dissemination of ' $C a$. Liberibacter spp.' Two species of Liberibacter have been documented in Brazil and Reunion Island, France. There is every reason to expect that further distribution of existing species and the discovery of additional species will

Table 2. Detection of 'Canditatus Liberibacter solanacearum' in qPCR assays using primers and probe from the rpoB region of ' $C a$. Liberibacter' in comparison with 'Ca. L. solanacearum' specific primers and probe

\begin{tabular}{|c|c|c|c|}
\hline Plant/psyllid samples & $\begin{array}{l}\text { Cq values obtained with the } \\
\text { primers and probe from the } \\
\text { rpoB region }\end{array}$ & $\begin{array}{l}\text { Cq values obtained with the } \\
\text { 'Ca. Liberibacter solanacearum' } \\
\text { specific primers and probe }\end{array}$ & $\begin{array}{c}\text { Estimated target bacteria } \\
\text { per } \mu \mathbf{l}^{\mathrm{a}}\end{array}$ \\
\hline Potato psyllids DNA $4.5 \mathrm{ng}$ & 34.22 & 25.83 & $3.37 \mathrm{E}+04$ \\
\hline Potato psyllids DNA $0.45 \mathrm{ng}$ & 38.36 & 29.56 & 2542 \\
\hline Potato psyllids DNA $0.045 \mathrm{ng}$ & Undetermined & 33.35 & 184.1 \\
\hline Tomato 2 & 35.08 & 25.98 & $3.03 \mathrm{E}+04$ \\
\hline Tomato 3 & 37.02 & 27.49 & $1.07 \mathrm{E}+04$ \\
\hline Tomato 4 & 35.71 & 23.68 & $1.50 \mathrm{E}+05$ \\
\hline Tomato 5 & 37.51 & 24.27 & $9.94 \mathrm{E}+04$ \\
\hline Tomato 6 & 36.12 & 21.38 & $7.34 \mathrm{E}+05$ \\
\hline Tomato 7 & 38.57 & 28.62 & 4864 \\
\hline Tomato 8 & 36.08 & 25.2 & $5.23 \mathrm{E}+04$ \\
\hline Carrot1 (Norway) & 33.34 & 29.78 & 2182 \\
\hline Carrot2 (Norway) & 33.66 & 29.8 & 2155 \\
\hline Carrot3 (Norway) & 34.24 & 29.94 & 1952 \\
\hline Carro4 (Norway) & 33.34 & 29.33 & 2976 \\
\hline Carrot5 (Sweden) & 32.5 & 29.07 & 3557 \\
\hline Carrot6 (Sweden) & 33.28 & 28.59 & 4982 \\
\hline Carrot7 (Sweden) & 34.97 & 30.38 & 1440 \\
\hline Carrot8 (Sweden) & Undetermined & 35.76 & 34.63 \\
\hline Zebra chip plant 1 & Undetermined & 33.96 & 120.4 \\
\hline Zebra chip plant 2 & Undetermined & 36.31 & 23.61 \\
\hline Zebra chip plant 3 & Undetermined & 34.45 & 85.85 \\
\hline Zebra chip plant 4 & Undetermined & 35.9 & 31.37 \\
\hline Zebra chip plant 5 & Undetermined & 36.44 & 21.63 \\
\hline Zebra chip plant 6 & Undetermined & 37.72 & 8.907 \\
\hline Zebra chip plant 7 & Undetermined & 39.17 & 3.263 \\
\hline 'Ca. L. asiaticus' infected citrus sample & 24.68 & Undetermined & $\mathrm{N} / \mathrm{A}^{\mathrm{b}}$ \\
\hline Healthy potato DNA & Undetermined & Undetermined & N/A \\
\hline Water control & Undetermined & Undetermined & N/A \\
\hline
\end{tabular}

a The standard curve with a $R^{2}$ of 0.991 . It was obtained with a dilution of cloned target with the ' $\mathrm{Ca}$. Liberibacter solanacearum' specific primer and probe set. Undetermained = no signal; N/A = not applicable.

b This was a natural sample, and therefore the target bacterial concentration was unknown. Used as a positive control for ' $\mathrm{Ca}$. L. asiaticus'. 
continue to occur. These events can be efficiently documented by these new assays.

\section{Acknowledgments}

We thank N. Wang and P. Trivedi, University of Florida, for providing DNA samples from citrus endophytes.

\section{Literature Cited}

1. Adékambi, T., Drancourt, M., and Raoult, D. 2009. The rpoB gene as a tool for clinical microbiologists. Trends Microbiol. 17:37-45.

2. Borukhov, S., and Nudler, E. 2003. RNA polymerase holoenzyme: Structure, function and biological implications. Curr. Opin. Microbiol. 6:93-100.

3. Case, R. J., Boucher, Y., Dahllöf, I., Holmström, C., Doolittle, W. F., and Kjelleberg, S. 2007. Use of 16S rRNA and rpoB genes as molecular markers for microbial ecology studies. Appl. Environ. Microbiol. 73:278-288.

4. Chen, J., Pu, X., Deng, X., Liu, S., Li, H., and Civerolo, E. 2009. A phytoplasma related to 'Candidatus Phytoplasma asteris' detected in citrus showing huanglongbing (yellow shoot disease) symptoms in Guangdong, P. R. China. Phytopathology 99:236-242.

5. Crosslin, J. M., Lin, H., and Munyaneza, J. E. 2011. Detection of 'Candidatus Liberibacter Solanacearum' in the Potato Psyllid, Bactericera cockerelli (Sulc), by Conventional and Real-Time PCR. Southwestern Entomol. 36:125-135.

6. Dahllöf, I., Baillie, H., and Kjelleberg, S. 2000. rpoB-based microbial community analysis avoids limitations inherent in 16S rRNA gene intraspecies heterogeneity. Appl. Environ. Microbiol. 66:3376-3380.

7. Damsteegt, V. D., Postnikova, E. N., Stone, A. L., Kuhlmann, M., Wilson, C., Sechler, A. J., Schaad, N. W., Brlansky, R. H., and Schneider, W. L. 2010. Murraya paniculata and related species as potential host and inoculum reservoirs of 'Candidatus Liberibacter asiaticus', causal agent of Huanglongbing. Plant Dis. 94:528-533.

8. Drancourt, M., and Raoult, D. 2002. rpoB gene sequence-based identification of Staphylococcus species. J. Clin. Microbiol. 40:1333-1338.

9. Duan, Y. P., Zhou, L. J., Hall, D., Li, W. B., Doddapaneni, H., Lin, H., Liu, L., Vahling, C. M., Gabriel, D., Williams, K. P., Dickerman, A., Sun, Y., and Gottwald, T. R. 2009. Complete genome sequence of citrus huanglongbing bacterium, 'Candidatus Liberibacter asiaticus' obtained through metagenomics. Mol. Plant-Microbe Interact. 22:1011-1020.

10. Gottwald, T. R., da Graça, J. V., and Bassanezi, R. B. 2007. Citrus huanglongbing: The pathogen and its impact. Plant Health Progress doi:10.1094/PHP-2007-0906-01-RV

11. Halbert, S. E., and Manjunath, K. L. 2004. Asian citrus pysllids (Sternorrhycha: Psyllidae) and greening disease of citrus: A literature review and assessment of risk in Florida. Fla. Entomol. 87:330-353.

12. Hansen, A. K., Trumble, J. T., Stouthamer, R., and Paine, T. D. 2008. A new huanglongbing species, 'Candidatus Liberibacter psyllaurous,' found to infect tomato and potato, is vectored by the psyllid Bactericera cockerelli (Sulc). Appl. Environ. Microbiol. 74:5862-5865.

13. Jagoueix, S., Bové, J. M., and Garnier, M. 1996. PCR detection of the two 'Candidatus' Liberobacter species associated with greening disease of citrus. Mol. Cell. Probes 10:43-50.

14. Jin, D. J., and Gross, C. A. 1989. Three rpoBC mutations that suppress the termination defects of rho mutants also affect the functions of nusA mutants. Mol. Gen. Genet. 216:269-275.

15. Kim, B. J., Lee, S. H., Lyu, M. A., Kim, S. J., Bai, G. H., Chae, G. T., Kim, E. C., Cha, C. Y., and Kook, Y. H. 1999. Identification of mycobacterial species by comparative sequence analysis of the RNA polymerase gene $(r p o B)$. J. Clin. Microbiol. 37:1714-1720.

16. Kim, J. S., and Wang, N. 2009. Characterization of copy numbers of 16 S rDNA and 16S rRNA of Candidatus Liberibacter asiaticus and the implication in detection in planta using quantitative PCR. BMC Research Notes 2009, doi:10.1186/1756-0500-2-37

17. Ko, K. S., Lee, H. K., Park, M. Y., Lee, K. H., Yun, Y. J., Woo, S. Y., Miyamoto, H., and Kook, Y. H. 2002. Application of RNA polymerase beta-subu- nit gene $(r p o B)$ sequences for the molecular differentiation of Legionella species. J. Clin. Microbiol. 40:2653-2658.

18. Lee, S. H., Kim, B. J., Kim, J. H., Park, K. H., Kim, S. J., and Kook, Y. H. 2000. Differentiation of Borrelia burgdorferi sensu lato on the basis of RNA polymerase gene (rpoB) sequences. J. Clin. Microbiol. 38:2557-2562.

19. Li, W., Hartung, J. S., and Levy, L. 2006. Quantitative real-time PCR for detection and identification of 'Candidatus Liberibacter species' associated with citrus huanglongbing. J. Microbiol. Methods 66:104-115.

20. Li, W., Li, D., Tweig, E., Hartung, J. S., and Levy, L. E. 2008. Optimized quantification of unculturable 'Candidatus Liberibacter spp.' in host plants using real-time PCR. Plant Dis. 92:854-861.

21. Liao, X. L., Zhu, S. F., Zhao, W. J., Luo, K., Qi, Y. X., Chen, H. Y., He, K. and Zhu, X. X. 2004. Cloning and sequencing of citrus huanglongbing pathogen $16 \mathrm{~S}$ rDNA and its detection by real-time fluorescent PCR. J. Agric. Biotechnol. 12:80-85.

22. Liefting, L. W., Weir, B. S., Pennycook, S. R., and Clover, G. R. G. 2009. 'Candidatus Liberibacter solanacearum', associated with plants in the family Solanaceae. Int. J. Syst. Evol. Microbiol. 59:2274-2276.

23. Magomere, T. O., Obukosia, S. D., Mutitu, E., Ngichabe, C., Olubayo, F., and Shibairo, F. 2009. Molecular characterization of 'Candidatus Liberibacter' species/strains causing huanglongbing disease of citrus in Kenya. Electronic J. Biotechnol. Vol. 12, No. 2.

24. Mollet, C., Drancourt, M., and Raoult, D. 1997. rpoB sequence analysis as a novel basis for bacterial identification. Mol. Microbiol. 26:1005-1011.

25. Munyaneza, J. E. 2010. Psyllids as vectors of emerging bacterial diseases of annual crops. Southwestern Entomologist 35(3):471-477.

26. Munyaneza, J. E. 2012. Zebra chip disease of potato: Biology, epidemiology, and management. Am. J. Pot Res. DOI 10.1007/s12230-012-9262-3

27. Munyaneza, J. E., Fisher, T. W., Sengoda, V. G., Garczynski, S. F., Nissinen, A., and Lemmetty, A. 2010. Association of "Candidatus Liberibacter solanacearum" with the psyllid Trioza apicalis (Hemiptera: Triozidae). Eur. J. Econ. Entomol. 103:1060-1070.

28. Munyaneza, J. E., Fisher, T. W., Sengoda, V. G., Garczynski, S. F., Nissinen, A., and Lemmetty, A. 2010. First report of "Candidatus Liberibacter solanacearum" in carrots in Europe. Plant Dis. 94:639.

29. Okuda, M., Matsumoto, M., Tanaka, Y., Subandiyah, S., and Iwanami, T. 2005. Characterization of the $t u f \mathrm{~B}-s e c \mathrm{E}-n u s \mathrm{G}-r p l \mathrm{KAJL} r p o \mathrm{~B}$ gene cluster of the citrus greening organism and detection by loop-mediated isothermal amplification. Plant Dis. 89:705-711.

30. Renesto, P., Gouvernet, J., Drancourt, M., Roux, V., and Raoult, D. 2001 Use of rpoB gene analysis for detection and identification of Bartonella species. J. Clin. Microbiol. 39:430-437.

31. Teixeira, D. C., Saillard, C., Couture, C., Martins, E. C., Wulff, N. A., Jagoueix, S. E., Yamamoto, P. T., Ayres, A. J., and Bové, J. M. 2008. Distribution and quantification of 'Candidatus Liberibacter americanus', agent of huanglongbing disease of citrus in São Paulo State, Brazil, in leaves of an affected sweet orange tree as determined by PCR. Mol. Cell. Probes 22:139-150.

32. Teixeira, D. C., Wulff, N. A., Martins, E. C., Kitajima, E. W., Bassanezi, R., Ayres, A. J., Eveillard, S., Saillard, C., and Bové, J. M. 2008. A phytoplasma closely related to the pigeon pea witches'-broom phytoplasma (16S r IX) is associated with citrus huanglongbing symptoms in the state of São Paulo, Brazil. Phytopathology 98:977-984.

33. Tian, Y., Ke, S., and Ke, C. 1996. Polymerase chain reaction for detection and quantification of Liberobacter asiaticum, the bacterium associated with huanglongbing (greening) of citrus in China. Pages 252-257 in: Proc. 13th Conf. Int. Organ. Citrus Virol. J. V. da Graça, P. Moreno, and R. K. Yokomi, eds. International Organization of Citrus Virologists, Riverside, CA

34. Villechanoux, S., Garnier, M., Renaudin, J., and Bové, J. M. 1992. Detection of several strains of the bacterial-like organism of citrus greening disease by DNA probes. Curr. Microbiol. 24:89-95.

35. Wang, Z., Yin, Y., Hu, H., Yuan, Q., Peng, G., and Xia, Y. 2006. Development and application of molecular-based diagnosis for 'Candidatus Liberibacter asiaticus', the causal pathogen of citrus huanglongbing. Plant Pathol 55:630-638. 